\title{
The concept of creating an information technology of process formation of the main educational programs based on professional competencies
}

\author{
Lilia Motaylenko \\ FSG-fEIHPE "Pskov State University», Faculty of Informatics. \\ Address: pl. Lenin 2, Pskov, 180000, Russia
}

\begin{abstract}
This paper gives the definition of information technology, describes the concept of creating an Information Technology of process formation of Main Educational Programs (IT MEP) based on professional competences and gives conceptual scheme of creating IT MEP.
\end{abstract}

Keywords: information technology, main educational program, professional competence, conceptual scheme, algorithm.

\section{INTRODUCTION}

Modern education in Russia is going through the stage of reforming, including changes of Federal State Educational Standards (FSES). Any reforming introduces into the system, in this context - the educational system, disturbances that lead to its instability. One of the tasks of creating information technology is a development of a sequence of actions that is operations, leading to the creation of control actions in order to stabilize the system.

Changes of FSES inevitably result in a change in the process of the formation of Basic Professional Educational Programs or Main Educational Programs (MEP) [1], their informative part, as well as a work plan. The following discussion focuses on the Higher Education (HE).

\section{INFORMATION TECHNOLOGIES. BASIC CONCEPTS AND DEFINITIONS}

Let's systematize basic concepts and definitions.

Before you decide, let's consider a general definition of technology.

Technology (from the ancient Greek: arts, skill, ability, thought, reason, method, mode of production) is a set of methods, processes and materials used in any field of business, as well as a scientific description of technical methods of production [2].

According to the Dictionary of Philosophy, edited by I. Frolov, "technology is a complex developing system of artifacts, manufacturing operations and processes, resource sources, subsystems of social consequences of information, management, financing and interaction with other technologies" [3].

Standard ISO / IEC 2382 - 1: 1993. Terms and Definitions (the Standard) [4] information (01.01.02) (in information processing) is any fact, concept, or meaning derived from Data (01.01.03) and associated context, or selected from Knowledge (01.01.01).

Data (01.01.03) Representation of Information (01.01.02) is representing information in some formalized manner suitable for communication, interpretation or processing [4].

The Standard does not define data as a source of information. Data are fixed values of different types. Fixing can be carried out both manually (by an observer) and automatically, i.e. by technical means. This concept is read from the definition of knowledge to have been processed. From this point of view information is data processed with manual or automatic methods which lead to their semantic recognition.

The concept of information technology is quite extensive.

The Standard specifies information technology (01.01.22) as an Art and applied sciences that deal with Data (01.01.03) and Information (01.01.02). The example of information technology is given: capture representation, processing, security, transfer, interchange, presentation, management, organization, Storage (12), and retrieval of data and information [4].

At the same time in the Federal Law of the Russian Federation "On Information, Information 
Technologies and Protection of information" [5] the definition is formulated somewhat differently:

"Information technologies are processes, methods for finding, collecting, storing, processing, representing, distributing information and ways to implement these processes and techniques."

The apparent difference is given in the methods mentioned above.

In the theory of information processes and systems basic information processes are listed, which are used as a part of IT [6], including the following operations: information extraction, transfer, processing, storage, presentation and usage.

Information technologies are a basis for creating information systems.

Defined by the Standard information system (1.1.13) is information processing system (01.01.12), together with associated organizational resources, that provides and distributes Information (01.01.02).

The information system is a combination of various resources and information technologies.

\section{CONCEPTUAL SCHEME}

The structure of the system described at the conceptual level allows to identify qualitatively main subsystems, components and connections among them $[6,7]$.

The conceptual scheme indicates entities that may exist in the area of a concern, i.e. entities that exist, existed or could ever exist. It also points out facts and events that are possible or required for these entities $[8,9]$.

The main role of the conceptual scheme is the following: to provide a common basis for understanding the general behavior of the total area of a concern, to determine the allowable evolution and the manipulation the information about the subject area, to provide a basis for the interpretation of external and internal syntactic forms, providing the information about the problem domain, to provide a basis for the transformation of external and internal schemes.

In the description of the conceptual scheme of the formation of MEP with the professional competencies the concepts such as class, entity, attribute, relationship are included.

Let's consider the conceptual scheme of the formation of MEP based on professional competencies (Fig. 1).

The classes of the conceptual scheme are experts, criteria, educational process.

Entities of the class Experts are outer experts that is inspectors who are representatives of higher institutions, employers who are potential employers for graduates, as well as inner experts: Staff and Students.

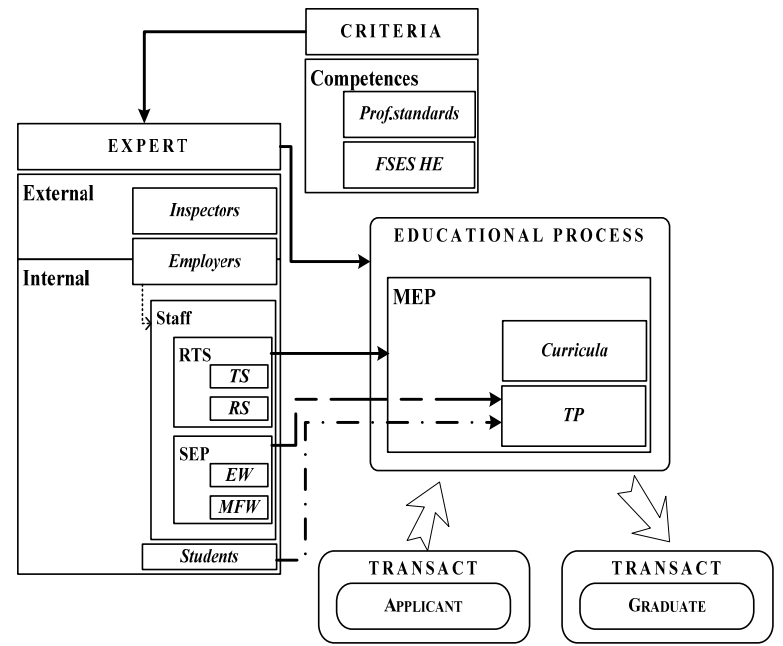

Fig. 1. Conceptual scheme of the formation of MEP based on professional competencies.

The FSES requirements on different directions require up to $30 \%$ of teachers training the students must be potential employers; in this connection the entity of Employers is an entity of the border between the inner and outer class of Experts, passing becoming the entity Staff.

The entity Staff includes Research and Teaching Staff (RTS), which includes Teaching Staff of (TS) and Researchers (RS); Staff supporting Educational Process (SEP) includes Engineering Workers (EW) and Methodical Field Workers (MFW) involved in the educational process.

The entity Students covers only those higher education students who have completed the study of a discipline or a discipline module [10].

The class Criteria includes the entity Competences of professional standards [11 - 13] and FSES HE.

The connection between classes Criteria and Experts is due to the subordination of the class Experts to the class Criteria.

The class Educational process includes the entity of MEP with elements of Curricula and Teaching Providing (TP).

RTS forms MEP and SEP is involved to the development of TP. The Students indirectly affect the change of TP after having been questioned on the discipline or the discipline module [10].

In the conceptual scheme (Fig. 1) elements of Transact are included. In the theory of mass servicing this concept is used to describe dynamic objects which while passing through the system changes its properties [14 - 17].

For the Educational Process such an object is an applicant being at the input of the process, who then acquires properties of a student according to the attributes and at the output process properties of a graduate with relevant direction competencies.

For this system the role of a specialist is left outside and is not considered. 
Fig. 2 shows the conceptual scheme of data streams in the Information System (IS) with selected basic IT processes and types of operations [4].

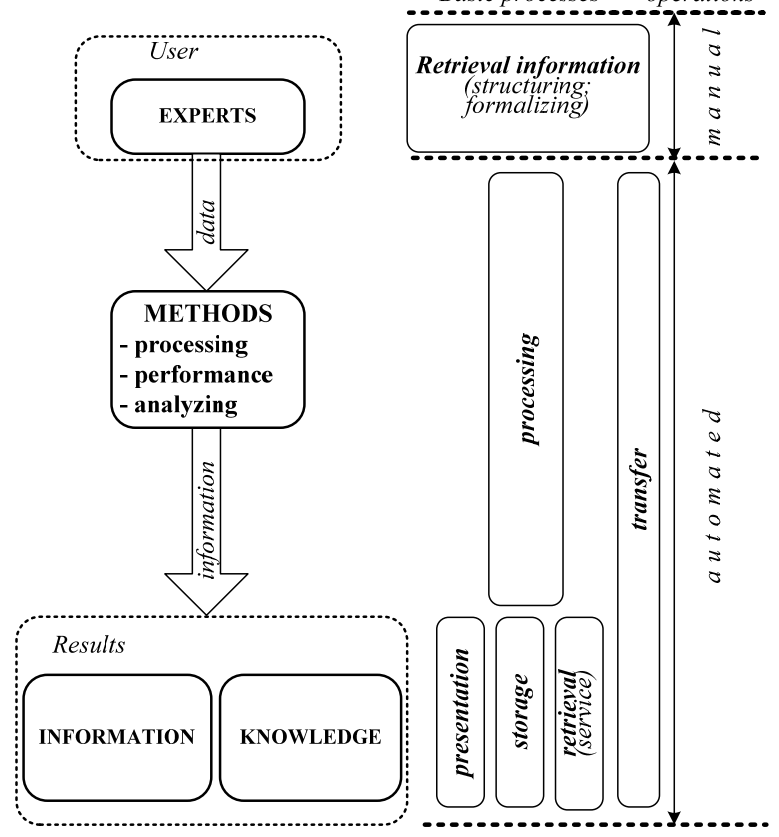

Fig. 2. Conceptual scheme of the data streams in IS.

Users are defined in the IS. The User is someone or something that sends commands and messages to the information system and receives messages from the information system. It is a part of the medium. Some users may have an authority to establish rules of a behavior or restriction for the information system [8]. The role of user Experts is to carry out a manual operation of the process of extracting information verbally stated, namely: structuring and formalizing i.e. representing data in the format of the machine representation.

All other processes are automated, i.e. they are performed by computers.

The methods, by means of which data are processed, refer to the collection of data for the distribution to entities of the class Teaching process, comparing criteria values [10], and analyzing the results. This processing lets obtain the resulting information and knowledge in accordance with the purpose, namely: to create the information technology of the process of the formation of main educational programs based on professional competencies.

The result of the work of the system is the information and the knowledge applied to improve the quality of the educational process. The Process of Presentation involves creating a user interface that displays the result obtained. Storage and Retrieval (service) processes provide the storage of created databases, knowledge bases, filtering operations, search, deleting outdated information.
The Transfer process consists of using local networks and data networks [18 - 20]. This system uses an application layer, which provides an access to shared network resources, network administrating, all kinds of electronic communication: e-mail, conferences, dialogue, etc.

The sequence of operations of the information technology of MEP forming process begins with determining the state of MEP (Fig. 3).

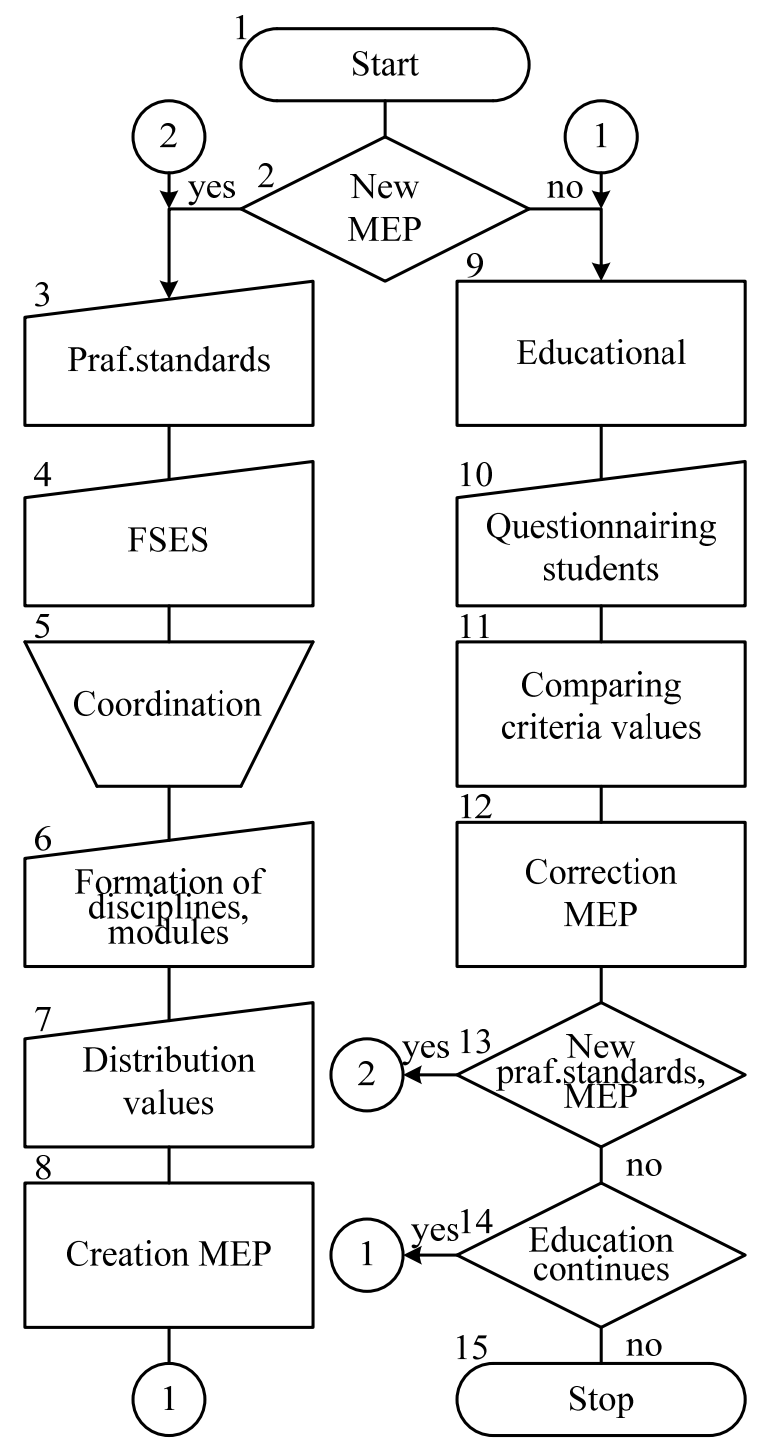

Fig. 3. Block diagram of the work algorithm of IS of the formation of MEP at the conceptual level.

The start of the algorithm of the information system block diagram is conditional. In case of opening a new direction in a college or in case of changing professional standards, FSES criteria or requirements to the graduates of a higher educational institution the introduction of new criteria and their coordination (manual operation, the implementation of which is provided by a user interface) is performed. The 
formation of disciplines and disciplines modules in accordance with the competencies and the distribution of their performance [10] in the curriculum (Fig. 1) is performed by Staff and then MEP is created.

In accordance with established MEP the training of students is provided. After completing the study of the discipline or the discipline module questionnairing the students on relevant indicators of acquired competences corresponding to distributed parameters is held (Competence area MEP and standard). If there is a difference Staff corrects teaching and methodological support of the discipline module as well as there may be done a redistribution of the competences and academic hours among disciplines, modules, i.e. the change of the curriculum.

At reforming the education system there appears a possibility of changing of MEP when new professional standards and FSES are approved or when new requirements of employers to the professional quality of graduates are introduced.

When the status of FSES is current (block 2) the actions are repeated according to the block diagram (Fig. 3) from connector 1. If the training program is no longer used (block 14) in the algorithm of work of information system the conditional stop (block 15) is indicated in block diagram.

\section{CONCLUSION}

The basic concepts and definitions of the theory of information technologies and systems given in the article, don't contradict current ISO and GOST.

The attention is focused on the need to harmonize the terminology database.

The concept of creating an information technology process of the formation of MEP with professional competencies as a conceptual diagram of the process of formation of MEP with the professional competencies and data flows in the information system is given.

The graphical presentation of the principle of the information system of the formation of MEP at the conceptual level is also shown.

\section{REFERENCES}

[1] Олейникова О.Н. Модульные технологии и разработка образовательных программ: учебное пособие / О.Н Олейникова, А. А. Муравьева, Ю. В. Коновалова, Е.В.Сартакова. Изд. 2-е, перераб. и доп., М.: Альфа-М; ИНФРА-М, 2010, $256 \mathrm{c.}$

[2] Севергин В. М. О предметах учений технологий // Технологический журнал. 1822. Т. 7. Ч. 1. С. 1.

[3] Философский словарь / под ред. И. Т. Фролова. - 7 изд., перераб. и доп. - М.: Республика, 2001. - 719 с.
[4] Термины и определения стандарта ISO/IEC 2382-1. Информационно-справочный портал MorePC.ru http://www.morepc.ru/informatisation/iso2381-1.html?print

[5] Федеральный закон от 27 июля 2006 г. N 149-Ф3 "Об информации, информационных технологиях и о защите информации" (с изменениями от 27 июля 2010 г., 6 апреля, 21 июля 2011 г., 28 июля 2012 г.). Принят Государственной Думой 8 июля 2006 года. Одобрен Советом Федерации 14 июля 2006 года

[6] Теория информационных процессов и систем: учебное пособие для студ. высш. учеб. заведений/ [Б. Я. Советов, В. А. Дубенецкий, В. В. Цехановский и др.]; под ред. Б.Я. Советова, М.: Издательский центр «Академия», 2010, 432 c.

[7] О'Коннор Дж. Искусство системного мышления: необходимые знания о системах и творческом подходе к решению проблем/ Дж. О’Коннор, И. Макдермот., М.: Альпина Бизнес Букс, 2006, 256 с.

[8] ГОСТ 34.320-96 Информационные технологии. Система стандартов по базам данных. Концепции и терминология для концептуальной схемы и информационной базы. Дата введения в действие 30.06.2001 .Код ОКС 35.100.01;35.240, 46c.

[9] Мотайленко Л.В., Антонов И.В. Методика и средство автоматизации работы выпускающей кафедры// Качество подготовки специалистов и научные исследования в Вузах: Доклады. Международная научно-практическая конференция - XIV Академические чтения МАН ВШ, Псков: Изд-во ППИ, 2009, С. 120 - 126

[10] L. Motaylenko, O. Poletayeva, S. Lyokhin Development of information model of forming basic educational programs in the light of professional competencies // Environment. Technology. Resources: Proceedings of the 9th International Scientific and Practical Conference, June 20-22, 2013. Vol. II. Rezekne, 2013.

[11] Олейникова О.Н., Муравьева А.А. Профессиональные стандарты: принципы формирования, назначение и структура. Методическое пособие, М.: АНО Центр ИРПО, 2011, $100 \mathrm{c}$.

[12] Профессиональные стандарты как основа подготовки конкурентоспособных работников: Методическое пособие / М. В. Привезенцев, О. Н. Олейникова, А. А. Муравьева и др., М.: Альфа-М, 2007, 160 с.

[13] Мотайленко Л.В., Полетаев Д.И. Методика интеграции образования и профессионального сообщества на базе информационных технологий// Информатика и образование: Научно-методический журнал, №9 (248), 2013, С. 51-54

[14] Авдеев О.Н., Мотайленко Л.В. Моделирование систем: учебное пособие, СПб.: СПбГТУ, 2001, 179c.

[15] Власов Л.В., Колесников Д.Н., Сорокин И.А. Имитационное моделирование систем массового обслуживания с использованием GPSS: Учеб. пособие, Л.: ЛПИ, 1989.

[16] Марков А.А. Моделирование информационновычислительных процессов: Учебное пособие для вузов, М.: Изд-во МГТУ им. Н.Э. Баумана, 1999, 360с.

[17] Нейлор Т. Машинные имитационные эксперименты с моделями экономических систем: Пер. с англ., М.: Мир, 1975.

[18] Барри Нанс. Компьютерные сети. /Пер. с англ., М.: БИНОМ, 1995.

[19] Олифер В.Г., Олифер Н.А. Компьютерные сети. Принципы, технологии, протоколы, СПб.: Питер, 1999 Советов Б.Я. Информационные технологии: учеб. для вузов/ Б.Я. Советов, В.В. Цехановский. - 3-е изд., стер., М.: Высш. шк., 2006, 263 с. 